\title{
Vulnerability of Structural Concrete to Extreme Climate Variances
}

\author{
Sakdirat Kaewunruen ${ }^{1, *}$ (D) , Lei $\mathrm{Wu}^{2}{ }^{2}$, Keiichi Goto ${ }^{3}$ and Yanuar Muhammad Najih ${ }^{3}$ \\ 1 TOFU Lab (Track Engineering and Operation for Future Uncertainties Laboratory), School of Engineering, \\ University of Birmingham, Birmingham B152TT, UK \\ 2 Department of Civil Engineering, School of Engineering, University of Birmingham, \\ Birmingham B152TT, UK; lxw415@alumni.bham.ac.uk \\ 3 Birmingham Centre for Railway Research and Education, School of Engineering, University of Birmingham, \\ Birmingham B152TT, UK; k.goto@bham.ac.uk (K.G.); ymn626@alumni.bham.ac.uk (Y.M.N.) \\ * Correspondence: s.kaewunruen@bham.ac.uk; Tel.: +44-0-121-414-2670
}

Received: 15 April 2018; Accepted: 10 May 2018; Published: 12 May 2018

\begin{abstract}
For modern infrastructures, structural concrete has been widely adopted for various components and structures such as railway stations, platforms, walkways, railway bridges, tunnelling, concrete sleepers, concrete foundation of overhead wiring structures, etc. These infrastructures are subject to various changes of time, operation, and environment. Environmental conditions are a considerably influential factor to life cycle and durability of concrete structures. This study aims at identifying the influence of climate change on the performance and durability of concrete structures using statistical regression analysis of a number of pertinent experimental and field data. The study into the influence of elevated temperature on compressive strength and splitting tensile strength also has been carried out using experimental data on the basis of environmental temperature and relative humidity, as well as $\mathrm{CO}_{2}$ concentration to the concrete carbonation and steel corrosion rates. The results indicate that environmental temperature, $\mathrm{CO}_{2}$ concentration, and a certain range of relative humidity play an important role in the concrete carbonation rates. Temperature and relative humidity affect the rate of steel corrosion as well. In addition, it is found that there exists a nearly direct correlation between the environmental temperature and the concrete carbonation rates, as well as the corrosion rate of steel embedded in concrete from $25^{\circ} \mathrm{C}$ to $60^{\circ} \mathrm{C}$, and a nearly inverse proportion between the environmental relative humidity and the concrete carbonization from $48.75 \%$ to $105 \%$. Indeed, the results exhibit that even in extreme natural high temperature, the capacity of compressive strength and splitting tensile strength is not affected significantly.
\end{abstract}

Keywords: climate variances; compressive strength; splitting tensile strength; temperature; relative humidity; $\mathrm{CO}_{2}$ concentration; carbonation of concrete; corrosion of steel

\section{Introduction}

Climate change has been in the spotlight for policy makers and practitioners over the past few years. The issue has been raised as a global political, economic, social, scientific, and technological problem. Engineering structures should not be designed by merely considering the requirements for safety (strength) and serviceability, but there is also a need to focus on reliability and durability [1]. In order to achieve high durability of structures, governments and building research institutes such as BRE (Building Research Establishment) have carried out some design standards and codes (e.g., UK standards, Eurocodes, etc.) and engineering practices aimed at protecting people and property from normal or foreseeable climate variation. The normal climate variation is based on statistical results of historical weather records. In general, this normal climate variation is randomly exceeded. 
However, in recent years, the increase in frequency of severe weather patterns can be evident due to climate change [2]. In other words, civil engineering structures are inevitably exposed to various impacts of climate change in terms of adverse changes in frequency, magnitude, scope, and scale of consequences. This can directly influence the safety, durability, and reliability of engineering structures.

'Extreme climate' has been applied to situations where the average condition of the weather event is severe or the extreme weather events occur during this period successively [2]. According to Planton et al. [3], extreme climate is defined using statistical theory that extreme events have either low frequency of occurrence, which refers to a threshold with $10 \%$ of values lower and $90 \%$ of values higher (as shown in Figure 1), or severe consequences due to these extreme events. In other words, the extreme climate and weather are significantly different from average conditions and seldom happen.

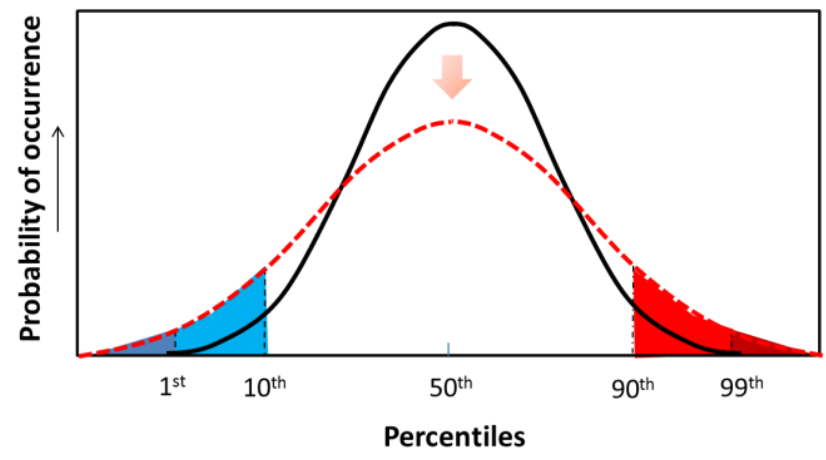

Figure 1. The threshold of extreme events percentiles. Climate variances can occur at both extreme conditions of low or high temperature. This data shows that the extreme climates at both ends can affect infrastructures at various scopes and scales.

In recent years, climate change is considered as a likely inducement of many other extreme events, which can damage or even destroy buildings, bridges, and other engineering structures. Such examples are heavy rainstorms, hurricanes, heat waves, high/low temperature, and so on. The increasing frequency of rainstorm events can lead to increased flood intensity. The strength of cement-based masonry structures will be reduced after being soaked for a long time and the building can be damaged directly. Because of this, the durability and security of buildings are under great threat. In 1998, a severe flooding caused buildings to collapse and resulted in $\$ 685$ million lost and 4150 people's deaths in China. If the wind speed increases by just $6 \%$, millions of buildings will be damaged by varying degrees. That consequence can contribute to $\$ 2$ billion in losses [4]. As the climatic temperature increases, the moisture content in soils decreases. The weathering processes of soil will then be accelerated by the combination of heavy rain and wind. Because of this erosion, the building foundations and bridge piers will be undermined. Damage can appear in lower floors and shallow concrete foundations of buildings. According to various statistics [4-6], insurance claims can reach 400 million pounds in the UK due to many extreme climatic reasons [7-10]. Additionally, the increase of carbon dioxide concentration in the atmosphere will accelerate the carbonation rate of concrete. The performance of engineering structures, which were built using concrete or cement-based materials, will be affected in terms of durability. Generally, the service life of engineering structures is very long. For some important structures, the design service life is much longer than the initial prediction or expectation. This implies that these structures will face more complex, more severe climate change scenarios in the future. In order to improve the performance of engineering structures and reduce the losses, construction has to be considered in a different way to adapt for climate change.

Within this context, the objective of this paper is to adopt statistical data in order to identify the effect of increasing $\mathrm{CO}_{2}$ concentrations and global-warming-induced changes in temperature and humidity on the durability of concrete structures. The first part of the paper presents the trend of climate change by means of the Intergovernmental Panel on Climate Change (IPCC) [11]. Then, high 
frequencies of extreme events will be identified. This section also includes the temperature distribution and relative humidity distribution by statistical data in recent years. The following section describes some references which focus on the durability of concrete structures and other engineering structures. The paper then collects the different experiments data which relate to the properties and durability of concrete structures and analyse the results by using statistical techniques. After that, the analysis results from a case study will be compared with the design criteria to get comprehensive insight into design and maintenance of civil infrastructures in built environments.

\section{Materials and Methods}

According to IPCC [11], the trend of climate change can be identified and extreme high temperature, increasing $\mathrm{CO}_{2}$ concentration, and heavy rain will appear frequently. Therefore, the data for extreme high temperature, $\mathrm{CO}_{2}$ concentration, and relative humidity need to be collected. Focussing on the change in average surface temperature from the IPCC, the temperature increasing is particularly evident in Asia. Hence, the data from the temperature distribution of Beijing in China are collected. In addition, the distribution of relative humidity during 2007 to 2011 from the UK climate projections (UKCP), which is the government website, is collected for use in the case study. This study adopts the trend line analysis over collected data. The data are derived from experimental data, which directly relate to design inputs, including compressive strength, splitting tensile strength, and influence factors of carbonization and corrosion.

All these data can be combined and a trend line can be established. In order to obtain the representative in different data groups, the standard deviation is calculated and ranked in every group. After ranking the data, the groups with small standard deviation could be collected. This study adopts the mean of these small standard deviation groups that could represent their data sets. Then, the trend line of the average points could be estimated using the least square method. In addition, critical design thresholds in terms of various mechanical properties, carbonation depth, and other engineering aspects can be confirmed through British standard and Eurocode code. Compared with the critical design levels, the impact on civil structures under extreme climate can be evaluated.

\section{Global Climate Condition}

Climate change trends are shown in the fifth assessment report of the Intergovernmental Panel on Climate Change (IPCC) [11]. The IPCC pointed out that warming of climate systems is obvious and definite. The IPCC summarized that the temperature increased from $0.0045^{\circ} \mathrm{C}$ per decade in the past 150 years to $0.074{ }^{\circ} \mathrm{C}$ per decade in the past 100 years, and $0.177^{\circ} \mathrm{C}$ per decade in the past 25 years, which trends upward. As a result, the atmosphere and ocean are warming, polar ice caps are melting, and extreme events will be more frequent and more likely to take place. The Rail Safety and Standards Board (RSSB) [12] also drew a figure to show the similar trend through plotting the data from the IPCC [13], which is shown in Figure 2. According to this figure, extreme cold weather will occur rarely due to global warming. At the same time, there will be more hot weather in the tails of the distribution and more extreme hot weather will occur frequently. According to Chen and Lu [14], the probability distribution of the maximum temperature in Beijing, China can be shown by using a statistic model as shown in Figure 3.

In addition, the IPCC pointed out that the $\mathrm{CO}_{2}$ concentration indicated the increasing trend from 280 parts per million in 1750 to 380 parts per million in 2005 [2]. The report of the IPCC [11] showed an impact from recent climate-related extremes, such as heat waves, droughts, floods, cyclones, and other extreme events. The IPCC also suggested that combinations with extreme weather patterns will increase. For example, the frequency of heavy rain in summer will increase, which means high temperature and severe rain will appear together, and as a consequence, the combined effect of these extreme weather events will be more serious than the effect of individual climate change events on engineering structures. 


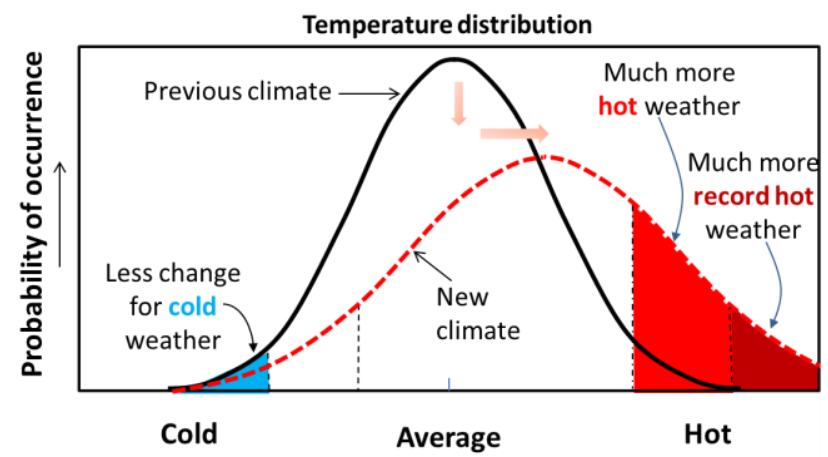

Figure 2. The temperature change between previous years and recent years, adopted from [11].

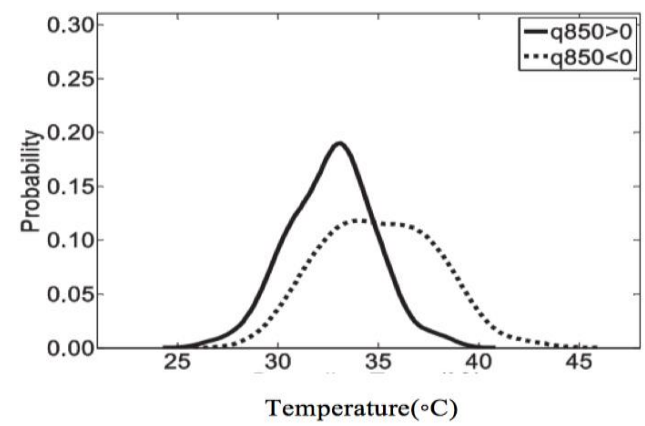

Figure 3. Probability distribution of maximum temperature in Beijing, China.

\section{Durability of Structural Concrete}

Hansson et al. [15] defined durability as the capacity of the structure to give a required performance during an intended service period under the influence of degradation mechanisms. Nireki [16] pointed out that the durability is related to the ability of structures to resist the deterioration, corrosion, and other damage over a period of time. In other words, the more durable the structure is, the longer its lifespan. Throughout the lifetime of a building, every structure will be subjected to a variety of environmental factors, e.g., changing temperatures and wind speeds. In order to fulfil the demand of the performance requirements during service life, it is important to take into account the durability.

According to People Insurance Company of China (PICC) statistics results of building structure types [17], concrete structures and composite steel and concrete structures made up 53.28\% of all types of structures in China in 2010. A large proportion of structures in North America, Europe, Australia, and China (including wharves and bridges) are concrete structures [17-23]. That means the concrete structures or buildings with concrete as part of their material account for a large proportion of different types of structures. Hence, this study focuses primarily on the durability of concrete.

According to a definition provided by Mehta [24], the durability of concrete is defined by its weathering action and ability to withstand chemical attack or any other process of deterioration in order to provide the original form, quality, and serviceability when exposed to any situations and environments. This definition is close to Hubert [25], who described concrete durability as the resistance to deteriorating influences, which may be through inadvertence or ignorance, residing within the concrete itself or which are inherent in the environment to which it is exposed. The structures described above can be divided into two groups: those which make use of concrete and steel reinforcement, and concrete, which consists of graded range aggregate combined with a cement paste [26]. Therefore, the deterioration of the concrete and corrosion of the reinforcement steel need to be identified. Yu and Bull [1] classified some conditions which can cause damage to and deterioration of concrete structures and are shown in Figure 4. 


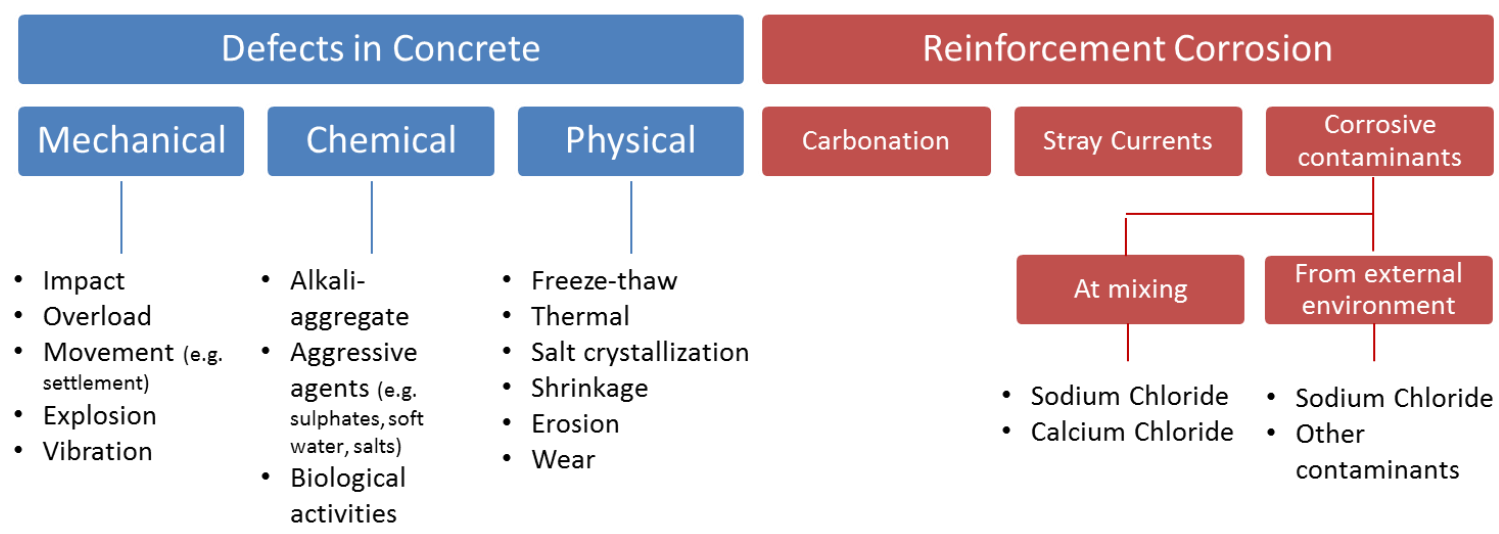

Figure 4. Deterioration of concrete and corrosion of reinforcement.

\section{Results for the Effects of Climate on Concrete}

Extreme temperatures can affect concrete. In particular, the influence on the design parameters such as compressive, tensile, and flexural strength is important. According to Solatiyan et al. [27], concrete pavements are generally exposed to temperatures of 20 degrees below zero, simulating a freeze-thaw situation. Freeze-thaw cycles can influence the properties of concrete significantly. The result can be shown in Figure 5.
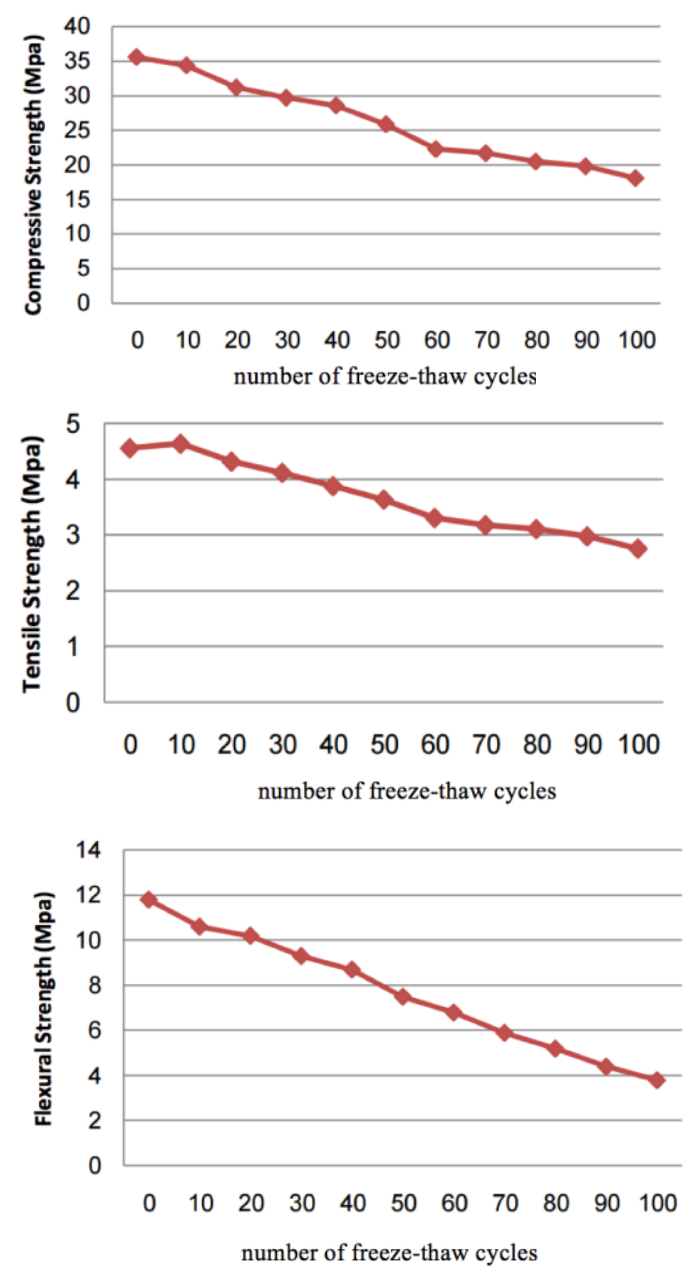

Figure 5. Freeze-thaw cycles on concrete. 
In addition, the low temperature can cause cracks. In a cold climate, any water which permeates the concrete surface through the concrete's pores will be frozen. As the water freezes, it expands by $9 \%$, thereby increasing pressure in the concrete. According to Solatiyan et al. [27], if the resulting stress is greater than the intrinsic tensile strength of reinforced concrete, a crack will occur. Moreover, if low temperature continues, the cracks will develop considerably [28]. High temperature also can have an influence on the performance of concrete. In order to highlight the influence, Ergün et al. [29] conducted an experiment by using three concrete test series using different water cement ratios-concrete $\mathrm{A}$ $(\mathrm{w} / \mathrm{c}=0.73)$, concrete $\mathrm{B}(\mathrm{w} / \mathrm{c}=0.60)$, and concrete $\mathrm{C}(\mathrm{w} / \mathrm{c}=0.48)$. The experimental results pointed out clearly that, as the temperature increases from 20 to 100 degrees Celsius, there is a very small increase in compressive strength. Above the water boiling point of 100 degree Celsius, the value of compressive strength shows the decline with the temperature increase, as shown in Figure 6.
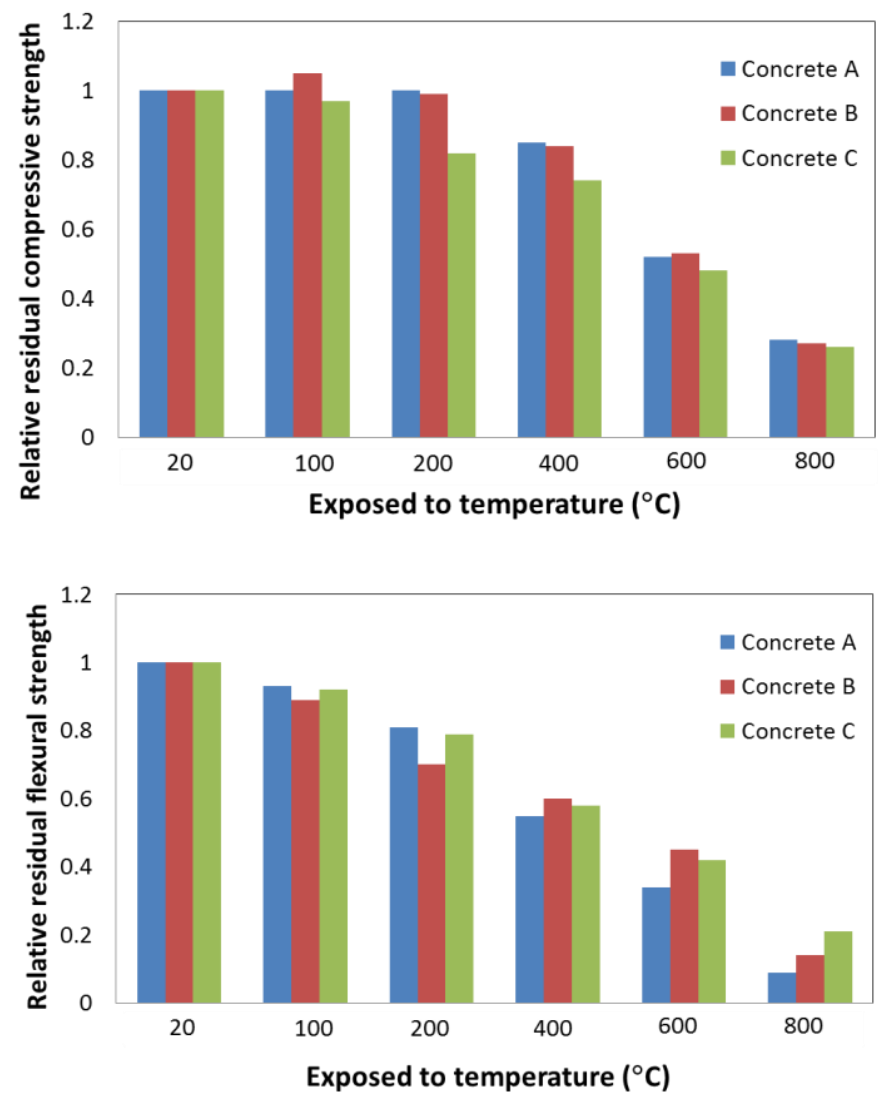

Figure 6. Effect of temperature on mechanical properties.

Figure 6 also demonstrates that the high temperature can affect the flexural strength dramatically, resulting in a weakened performance of flexural capacity. Additionally, the extreme temperature can influence the chemical reaction in concrete. An increase in temperature will result in higher corrosion rates when combined with $\mathrm{CO}_{2}$. Moreover, Ergün et al. [29] argued that when reinforced concrete is exposed to a high-temperature situation, the physical and chemical changes have a significant effect on the concrete material rather than the reinforcing steel bar material. In other words, a high temperature affects the mechanical strength loss of concrete more significantly than that of a steel bar. It was also found that the extreme temperature can influence the chemical process during hydration (the setting and hardening of concrete).

Climate change can modify the level of environmental humidity. The environmental humidity or moisture damping could also influence the internal water content of concrete. It is noted that the internal water content of concrete plays a significant role in the performance level of mechanical 
properties [30]. Li [31] measured the compressive strength, splitting tensile strength, and tensile strength of ring compression by using different water contents of concrete. The result showed that the increase of internal water content of concrete decreased the compressive strength and tensile strength of ring compression, whilst the change of splitting tensile strength was little. Additionally, the compressive strength and splitting tensile strength rose (by means of oven drying) in order to decrease the water content of the concrete, but the tensile strength of ring compression declined dramatically. However, although the experiment examined mechanical properties of concrete with various water contents, the past study did not investigate the critical level of different load-carrying capacities or strengths in damped surroundings. Climate change also can result in drying shrinkage of concrete. The relative humidity of the air, the increase in temperature, and the concrete mix determine the rate of the shrinkage of concrete [1].

In addition to the effect of a single extreme climate, the combined effect of extreme weather or multihazards could certainly be more serious. For example, after high precipitation, the concrete would suffer from heavy insulation [30]. This process can enable the internal water of concrete to undergo two physical processes, referring to the amount of absorption and evaporation, respectively. The concrete has the process of a drying-wetting cycle, which means its internal relative humidity goes from low to high, and then from high to low. Consequently, the effects of this wet-dry process are more severe than a single extreme climate effect (such as warmer temperature or heavier precipitation). It was found that the damage of concrete due to these processes will develop seriously [32-34]. The chemical reaction in concrete can decrease the performance of concrete structures [1]. There are two different types of chemical processes owing to the external environment which would affect the durability of concrete structures. The first is carbonation in concrete and the other is chloride penetration.

When the level of dampness increases, the probability of chloride corrosion also increases. In other words, the external environment of concrete, such as warmer temperature and heavier floods, would increase the potential of corrosion in the reinforcements. Once steel reinforcement undergoes corrosion, the properties of the whole concrete structure will be affected in terms of both strength and durability. With the intensification of corrosion, the process of deterioration will be severe, even resulting in a collapse of structure. Gjørv [35] indicated that in Figure 7, which shows the deterioration process due to steel corrosion based on empirical studies.

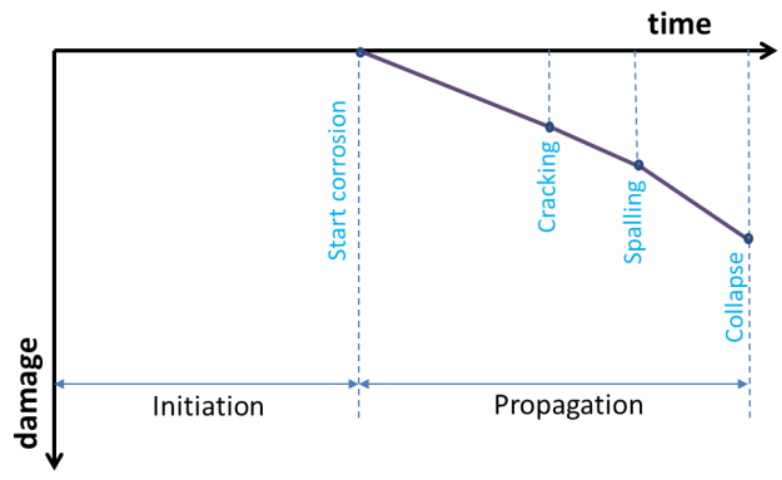

Figure 7. Deterioration process of concrete structures due to rebar corrosion.

Erosion and wear can also influence the durability of concrete structures. Yu and Bull [1] argued that erosion and wear are either physical processes or mechanical processes which can damage the dimensions of concrete. Natural sands and rocks, which are on the ground surface, can overcome gravity with strong wind and turbulence. The higher the sands and rocks jump, the more energy they have to damage concrete surfaces. When the concrete structures come into contact with the high-pressure windborne debris, the concrete surface abrades heavily. The other abrasion phenomenon appears in some areas which carry fast-flowing water such as dams, canals, rivers, and pipelines [1]. They also pointed out that the sudden change of water flow, such as velocity changing of flow, can 
result in cavitation as well as a percussive effect on concrete [1]. In many cases, the floods can also induce these negative features. For example, heavy rainfall and strong wind can affect the run-off flow rate and the level of floods can be heightened. In this case, the concrete structures, which are immersed in floods, would consequently experience aggressive abrasion.

The weathering generally means the physical deterioration of the outer skin of concrete caused by the effects of rain, frost, sunlight, and atmospheric pollution. Mays [26] and Tang et al. [36] pointed out that high-rise buildings tend to be influenced by weathering. Especially when heavy rain and strong wind occur concurrently, the weathering of high buildings will be intensive. However, the combined effect of two variables could exceed that of each variable separately $[6,10]$.

\section{Discussion on the Vulnerability of Concrete Structures under Extreme Climate}

Based on the data analyses, the durability and performance of concrete structures in built environments can be estimated under extreme climate. Structural concrete components could potentially fail below key strength criteria such as compression, tension, carbonation, and corrosion in aggressive environments, which can later be aggravated by the electrolysis effect (e.g., in railway tracks).

The compressive strength performance under high temperature based on the China and UK climate data can be shown in Figure 8. The horizontal and left vertical axes represent increasing temperature and relative residual compressive strength, respectively. In this figure, the distribution of natural temperature, which is shown in Figure 3, is also investigated. Different types of concrete can be identified by different colours. The differences between Concrete $\mathrm{A}, \mathrm{B}$, and $\mathrm{C}$ are original compressive stress, rebar diameter, and rebar grade [37]. C40 concrete is a high-performance concrete which is mixed with fly ash and super plasticizer [38]. Concrete M, H, A, and E, which are different in unit cement content and fly ash content, indicate the results of light concrete [39].

In this case study, the averages of compressive strength of various concrete data sets are calculated at every temperature. Based on these data sets, the trend line can be obtained using the least square method. It is found that the trend of compressive strength at a high temperature is distinctive. As the temperature increases, the strength clearly decreases. According to Figures 2 and $3,39^{\circ} \mathrm{C}$ to $45^{\circ} \mathrm{C}$ can be defined as range of extreme temperature. This implies that the range of temperature variances in China has very little effect on the compressive strength of concrete $(<6 \%)$.

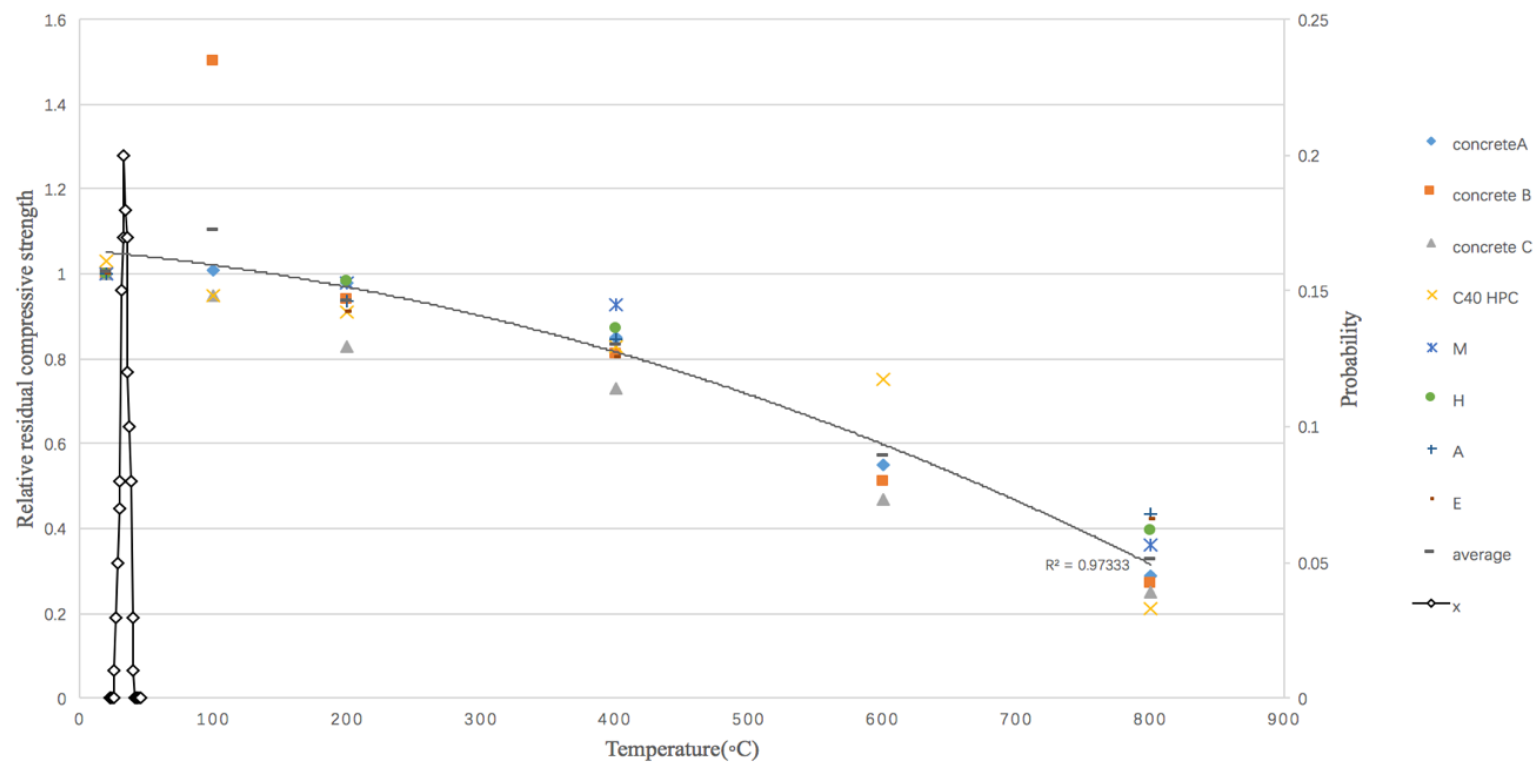

Figure 8. The performance of compressive strength subject to high temperature and distribution of natural temperature. 
Concrete is very weak in tension due to its brittle nature and is not expected nor designed to resist the direct tension. The crack is easy to extend along with the tensile stress plane direction, which means the tensile strength of concrete is generally much lower than compressive strength [40-45]. Therefore, the performance of splitting tensile strength subject to high temperature was also investigated in this study. The test data was obtained from different sources based on experimental data and empirical relations in different standards [46-50]. In experiments of Khaliq and Kodur [51], they tested the impact of elevated temperature on properties of concrete. There are three types of concrete which were presented in their experiments. Bahnood2009, Eurocode2, and SEPE HB are a high-performance concrete and two normal-strength concretes, respectively. The differences between Eurocode 2 and SEPE HB are the variations in water-cement ratio and aggregate. Khaliq and Kodur [51] conducted the study experimentally and statistically, which highlighted the effect of high temperature on splitting tensile strength between different types of concrete. High-strength concrete (HSC), self-consolidating concrete (SCC), fiber-reinforced concrete (FRC), and fly-ash concrete (FAC) were tested at various temperatures from $20^{\circ} \mathrm{C}$ to $800{ }^{\circ} \mathrm{C}$. The other data sets derived from other experiments [51] also are considered in this case evaluation. The four specimens $(\mathrm{M}, \mathrm{H}, \mathrm{A}$, and $\mathrm{E})$ with different amounts of fly ashes were heated from $20^{\circ} \mathrm{C}$ to $800{ }^{\circ} \mathrm{C}$. Data generated from these tests were used to establish the statistical trend line of splitting tensile strength at elevated temperature, which is displayed in Figure 9.

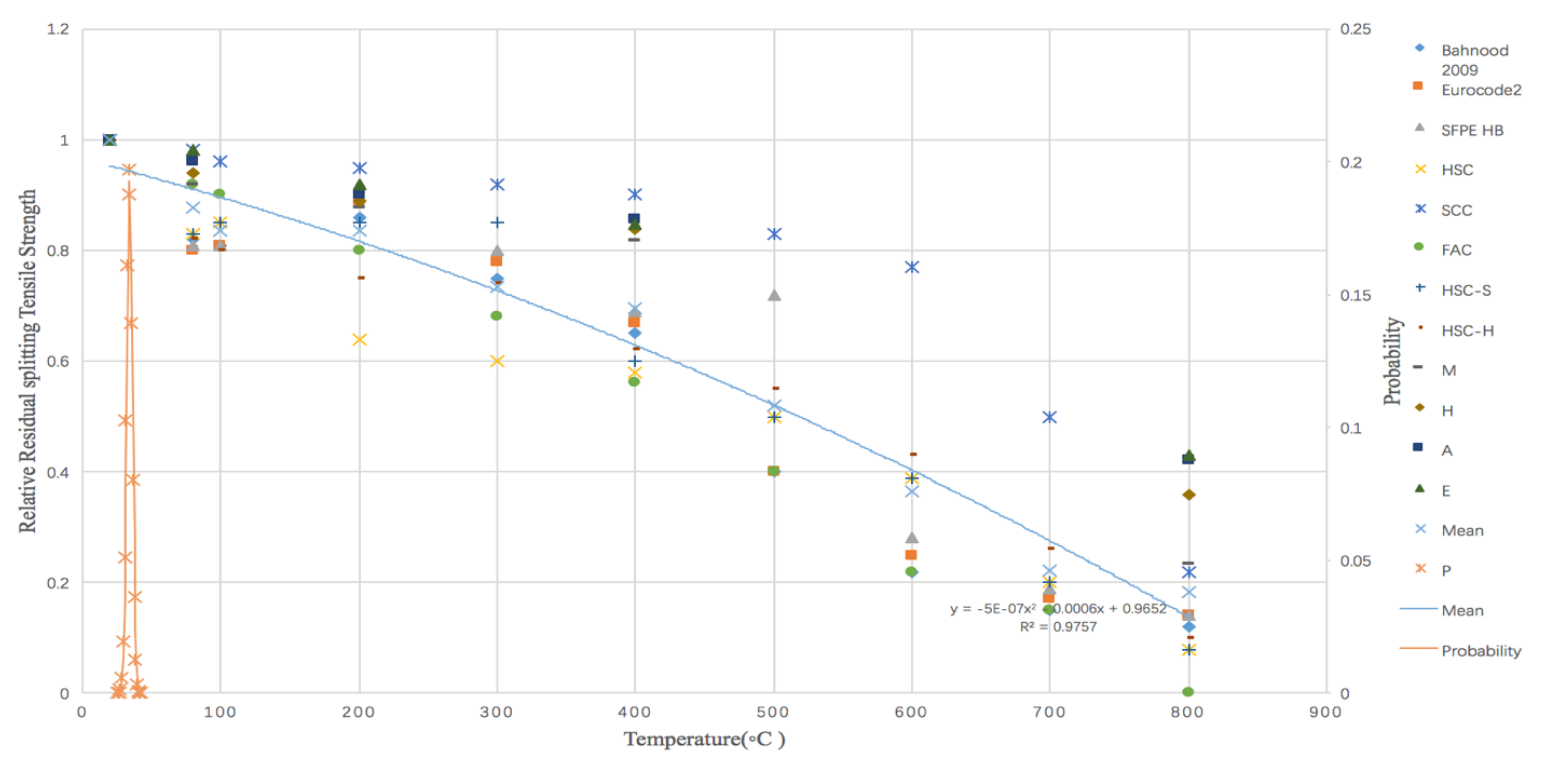

Figure 9. The performance under splitting strength subject to high temperature and distribution of natural temperature.

Using the average results of relative residual splitting tensile strength at every temperature, Figure 9 illustrates that the properties of splitting tensile strength decrease significantly as the temperature increases. Additionally, the properties of the high-performance concrete tend to drop much faster after heated whilst self-consolidating concrete tends to yield a gradual reduction in terms of splitting tensile strength at elevated temperature.

Carbonation is a widespread degradation of concrete and may be coupled with more severe degradations from other sources [52]. Carbonation is a significant factor that reduces the durability of concrete. Therefore, the investigation on the effect of climate change versus carbonation of concrete was carried out. Zhang et al. [53] used the experiment of accelerated carbonation method to study carbonization of concrete. They studied how the environmental situation influenced concrete carbonation depth. The experimental condition included a temperature range from $10{ }^{\circ} \mathrm{C}$ to $50{ }^{\circ} \mathrm{C}$, relative humidity of $70 \%$, and carbon dioxide concentration of $20 \%$. This case study collected the data from their experiment to identify the influence of temperature on carbonation from $10{ }^{\circ} \mathrm{C}$ to 
$50{ }^{\circ} \mathrm{C}$. Xu et al. [54] tested the carbonation occurring in low-calcium, fly-ash concrete. They used concrete specimens with different amounts of fly ash by controlling $20 \%$ concentration of $\mathrm{CO}_{2}, 10{ }^{\circ} \mathrm{C}$ to $30{ }^{\circ} \mathrm{C}$ temperature, and $50 \%$ to $70 \%$ relative humidity $(\mathrm{RH})$. The data related to carbonation on in the temperature range of $10^{\circ} \mathrm{C}$ to $30{ }^{\circ} \mathrm{C}$ were derived from this experiment. Atiş [55] also analyzed the relationship between fly-ash concrete and carbonation of concrete. Five concrete specimens were subjected to a temperature of 20 degrees with $3.75-4.25 \% \mathrm{CO}_{2}$ concentration. At $20{ }^{\circ} \mathrm{C}$, experimental data were derived and taken for statistical analysis in this study. The data, which are related to the relationship between temperature and carbonation of concrete, are shown in Figure 10.

Based on the distribution of data points in combination with the natural temperature distribution, the trend line, which represents the change over temperature, can be shown in Figure 10. In this figure, the left vertical axis provides the depth of carbonation with respect to carbonization degree and the horizontal axis shows the range of elevated temperature. The right vertical axis shows the occurrence probability of temperature in China. It can be confirmed that the environmental temperature has a significant influence on the carbonation rate of concrete [56]. The depth of carbonation increases with the increase in temperature. If the ambient weather condition can reach a higher level of temperature, the temperature of the concrete surface will be much higher compared with the ambient temperature. This means that elevated temperature can accelerate the rate of carbonation and can reduce the durability of concrete, as evident by other key research [57-63].

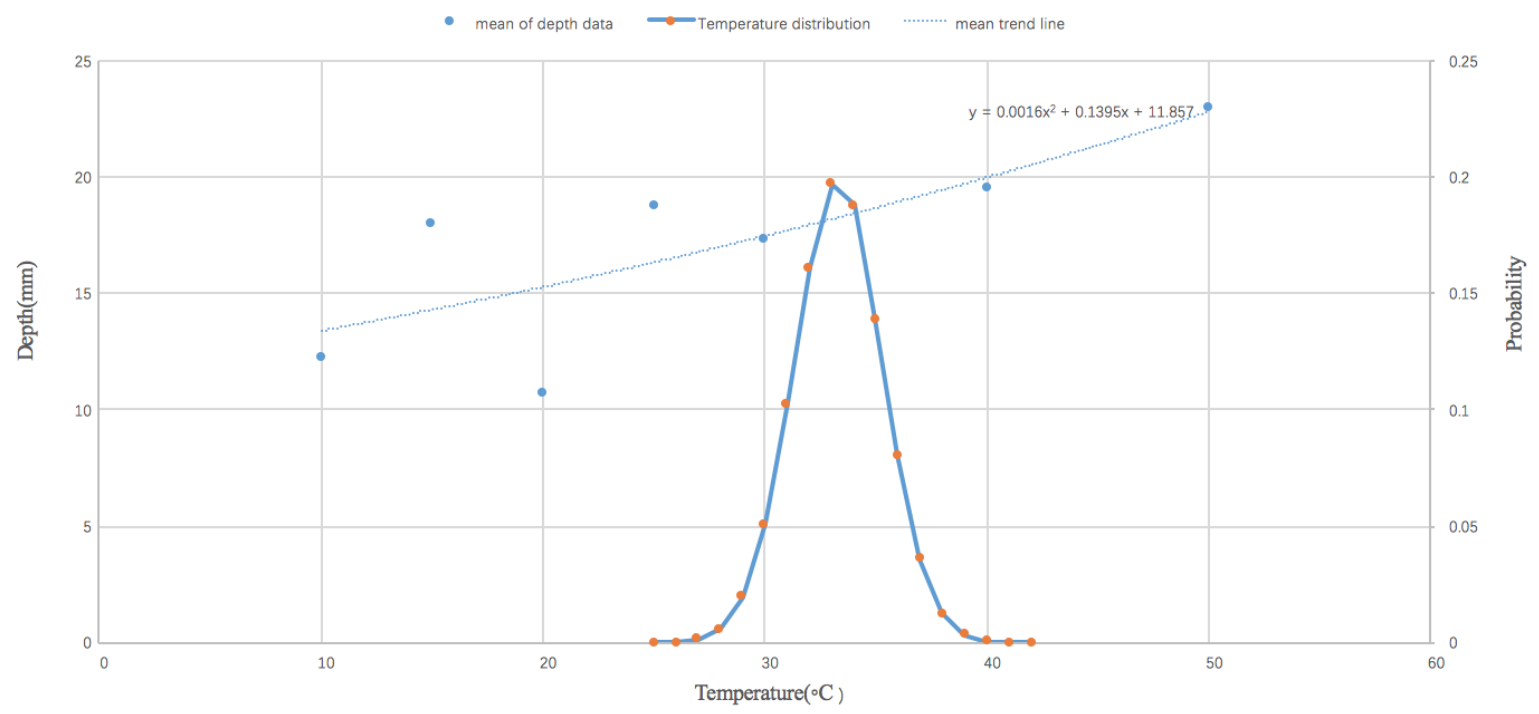

Figure 10. The relationship between depth of carbonation and ambient temperature.

\section{Conclusions}

This paper presents some critical considerations to assess the effect of extreme climate on the performance and durability of concrete structures. This study gathers the climate data from the IPCC and Chinese and British authorities, together with other experimental data from published research related to structural design parameters including compressive strength, splitting tensile strength, and influence factors of carbonization and corrosion. The trend line analysis using the least square method is adopted in this study. In order to obtain the representative data sets in various groups of experimental data, the standard deviation is calculated and ranked in every group. After ranking the data, the groups with small standard deviation could be collected for further analyses. Considering the research question posed at the beginning of this study, it is now possible to identify that the change of climate has different impacts on the mechanical properties and durability of concrete structures. Firstly, based on the climate variance in China and the UK, this study indicates that extreme climate temperature does not have a significant influence on the compressive strength and splitting tensile 
strength, with an exception for high-strength concrete. The performance of high-strength concrete is highly sensitive to extreme climate variances. Secondly, this study indicates that extreme high temperature could have an influence on the carbonization of concrete. It is very apparent that extreme high temperature could accelerate corrosion of reinforcement steel. This insight is vital for engineers to develop innovative solutions that could lead to improvement in the durability of concrete, such as high-damping concrete to reduce load effects, or self-healing concrete to minimise concrete porosity.

Author Contributions: L.W., K.G. and Y.M.N. analyzed the data; S.K. contributed materials and analysis tools; all authors wrote the paper.

Acknowledgments: The authors are sincerely grateful to European Commission for the financial sponsorship of the H2020-RISE Project No. 691135 “RISEN: Rail Infrastructure Systems Engineering Network," which enables a global research network that tackles the grand challenge in railway infrastructure resilience and advanced sensing in extreme environments (www.risen2rail.eu) [64]. In addition, this project is partially supported by European Commission's Shift2Rail, H2020-S2R Project No. 730849 “S-Code: Switch and Crossing Optimal Design and Evaluation".

Conflicts of Interest: The authors declare no conflict of interest.

\section{References}

1. Yu, C.W.; Bull, J.W. Durability of Materials and Structures in Building and Civil Engineering; Whittles Pub.: Oldham, UK, 2006.

2. Intergovernmental Panel on Climate Change (IPCC). Summary for Policymakers; IPCC: Geneva, Switzerland, 2007.

3. Planton, S.; Deque, M.; Chauvin, F.; Terray, L. Expected impacts of climate change on extreme climate events. C. R. Geosci. 2008, 340, 564-574. [CrossRef]

4. Lisø, K.R.; Aandahl, G.; Eriksen, S.; Alfsen, K. Preparing for climate change impacts in Norway's built environment. Build. Res. Inf. 2003, 31, 200-209. [CrossRef]

5. Lin-Ye, J.; García-León, M.; Gràcia, V.; Ortego, M.I.; Lionello, P.; Sánchez-Arcilla, A. Multivariate statistical modelling of future marine storms. Appl. Ocean Res. 2017, 65, 192-205. [CrossRef]

6. Lin-Ye, J.; García-León, M.; Gràcia, V.; Ortego, M.I.; Stanica, A.; Sánchez-Arcilla, A. Multivariate hybrid modelling of future wave-storms at the northwestern Black Sea. Water 2018, 10, 221. [CrossRef]

7. Milner, J.; Harpham, C.; Taylor, J.; Davies, M.; Le Quéré, C.; Haines, A.; Wilkinson, P. The challenge of urban heat exposure under climate change: An analysis of cities in the Sustainable Healthy Urban Environments (SHUE) database. Climate 2017, 5, 93. [CrossRef]

8. Breda Fontao, P.A.; Zavattini, J.A. Variations of rainfall rhythm in Alto Pardo Watershed, Brazil: Analysis of two specific years, a wet and dry one, and their relation with the river flow. Climate 2017, 5, 47. [CrossRef]

9. Steinke, V.A.; Palhares de Melo, L.A.M.; Torres Steinke, E. Rainfall variability in January in the Federal District of Brazil from 1981 to 2010. Climate 2017, 5, 68. [CrossRef]

10. Corbella, S.; Stretch, D.D. Multivariate return periods of sea storms for coastal erosion risk assessment. Nat. Hazards Earth Syst. Sci. 2012, 12, 2699-2708. [CrossRef]

11. Intergovernmental Panel on Climate Change (IPCC). Summary for Policymakers; IPCC: Geneva, Switzerland, 2014.

12. Rail Safety and Standards Boards (RSSB). Tomorrow's Railway and Climate Change Adaptation: Executive Report; RSSB: London, UK, 2016.

13. Intergovernmental Panel on Climate Change (IPCC). Summary for Policymakers; IPCC: Geneva, Switzerland, 2001.

14. Chen, R.; Lu, R. Dry Tropical Nights and Wet Extreme Heat in Beijing: Atypical Configurations between High Temperature and Humidity. Mon. Weather Rev. 2014, 142, 1792-1802. [CrossRef]

15. Hansson, F.E.; Brischke, C.; Meyer, L.; Isaksson, T.; Thelandersson, S.; Kavyrmaci, D. Durability of timber outdoor structures-Modelling performance and climate impacts. In Proceedings of the World Conference on Timber Engineering, Auckland, New Zealand, 16-19 July 2012.

16. Nireki, T. Service life design. Constr. Build. Mater. 1996, 10, 403-406. [CrossRef]

17. Wang, X.; Stewart, M.G.; Nguyen, M. Impact of climate change on corrosion and damage to concrete infrastructure in Australia. Clim. Chang. 2012, 110, 941-957. [CrossRef]

18. Binti Sa'adin, S.L.; Kaewunruen, S.; Jaroszweski, D. Risks of Climate Change with Respect to the Singapore-Malaysia High Speed Rail System. Climate 2016, 4, 65. [CrossRef]

19. Binti Sa'adin, S.L.; Kaewunruen, S.; Jaroszweski, D. Heavy rainfall and flood vulnerability of Singapore-Malaysia high speed rail system. Aust. J. Civ. Eng. 2016, 14, 123-131. [CrossRef] 
20. Binti Sa'adin, S.L.; Kaewunruen, S.; Jaroszweski, D. Operational readiness for climate change of Malaysia high-speed rail. Proc. Inst. Civ. Eng. Transp. 2016, 169, 308-320. [CrossRef]

21. Setsobhonkul, S.; Kaewunruen, S.; Sussman, J.M. Lifecycle Assessments of Railway Bridge Transitions Exposed to Extreme Climate Events. Front. Built Environ. 2017, 3, 35. [CrossRef]

22. Dindar, S.; Kaewunruen, S.; An, M.; Sussman, J.M. Bayesian Network-based probability analysis of train derailments caused by various extreme weather patterns on railway turnouts. Saf. Sci. 2018, in press. [CrossRef]

23. Ngamkhanong, C.; Kaewunruen, S.; Costa, B.J.A. State-of-the-Art Review of Railway Track Resilience Monitoring. Infrastructures 2018, 3, 3. [CrossRef]

24. Mehta, P.K. Concrete: Microstructure; McGraw-Hill Professional: New York, NY, USA, 2013.

25. Woods, H. Durability of Concrete Construction; American Concrete Institute and Iowa State U.P.: Detroit, MI, USA, 1968.

26. Mays, G. Durability of Concrete Structures: Investigation, Repair, Protection; CRC Press: Boca Raton, FL, USA, 2002.

27. Solatiyan, E.; Asadi, M.; Bozorgmehrasl, M. Investigating the Effect of Freeze-Thaw Cycles on Strength Properties of Concrete Pavements in Cold Climates. Indian J. Fundam. Appl. Life Sci. 2015, 5, 2231-6345.

28. Bijen, J. Durability of Engineering Structures: Design, Repair and Maintenance; CRC Press: Boca Raton, FL, USA, 2003.

29. Ergün, A.; Kürklü, G.; Başpınar, M.S. The effects of material properties on bond strength between reinforcing bar and concrete exposed to high temperature. Constr. Build. Mater. 2016, 112, 691-698. [CrossRef]

30. Zhou, F. Study on the Impacts of Climate Change on Building Engineering; Beijing Jiaotong University: Beijing, China, 2009.

31. Li, G. The Effect of Moisture Content on the Tensile Strength Properties of Concrete; University of Florida: Gainesville, FL, USA, 2004.

32. Kaewunruen, S.; Remennikov, A.M. Effect of a large asymmetrical wheel burden on flexural response and failure of railway concrete sleepers in track systems. Eng. Fail. Anal. 2008, 15, 1065-1075. [CrossRef]

33. Kaewunruen, S. Monitoring in-service performance of fibre-reinforced foamed urethane sleepers/bearers in railway urban turnout systems. Struct. Monit. Maint. 2015, 1, 131-157. [CrossRef]

34. Remennikov, A.M.; Kaewunruen, S. Experimental load rating of aged railway concrete sleepers. Eng. Struct. 2014, 76, 147-162. [CrossRef]

35. Gjørv, O. Durability Design of Concrete Structures in Severe Environments; CRC Press: Boca Raton, FL, USA, 2014.

36. Tang, W.; Davidson, C.I.; Finger, S.; Vance, K. Erosion of limestone building surfaces caused by wind-driven rain: 1. Field measurements. Atmos. Environ. 2004, 38, 5589-5599. [CrossRef]

37. Akono, A.-T.; Chen, J.; Kaewunruen, S. Friction and fracture characteristics of engineered crumb-rubber concrete at microscopic lengthscale. Constr. Build. Mater. 2018, 175, 735-745. [CrossRef]

38. Zhen, W.; Tao, H. Experimental Study on Residual Compressive Strength of C40 HPC at High Temperature and after Cooling. In Proceedings of the 2011 International Conference on Electric Technology and Civil Engineering (ICETCE), Lushan, China, 22-24 April 2011; pp. 336-339.

39. Tanyildizi, H.; Coskun, A. The effect of high temperature on compressive strength and splitting tensile strength of structural lightweight concrete containing fly ash. Constr. Build. Mater. 2008, 22, 2269-2275. [CrossRef]

40. Mindess, S.; Francis, J.; Darwin, D. Concrete; Prentice Hall, Pearson Education, Inc.: Upper Saddle River, NJ, USA, 2003.

41. Chan, S.Y.N.; Peng, G.; Chen, J.K.W. Comparison between high strength concrete and normal strength concrete subjected to high temperature. Mater. Struct. 1996, 29, 616-619. [CrossRef]

42. Gonen, T.; Yazicioglu, S. The influence of compaction pores on sorptivity and carbonation of concrete. Constr. Build. Mater. 2007, 21, 1040-1045. [CrossRef]

43. Ho, D.W.S.; Lewis, R.K. Carbonation of concrete and its prediction. Cem. Concr. Res. 1987, 17, $489-504$. [CrossRef]

44. Jiang, D.; Li, L.; Yuan, Y. Effect of humidity and temperature on Corrosion of reinforcing steel bar. J. Huaihai Inst. Technol. 2004, 1, 59-62.

45. Khaliq, W.; Kodur, V.K.R. Effect of High Temperature on Tensile Strength of Different Types of High-Strength Concrete. ACI Mater. J. 2011, 108, 394-402.

46. Hu, J.; Cheng, X.; Li, X.; Deng, P.; Wang, G. The Coupled Effect of Temperature and Carbonation on the Corrosion of Rebars in the Simulated Concrete Pore Solutions. J. Chem. 2015, 462605. [CrossRef] 
47. Peters, G.; DiGioia, A.M., Jr.; Hendrickson, C.; Apt, J. Transmission Line Reliability: Climate Change and Extreme Weather. In Electrical Transmission Line and Substation Structures; American Society of Civil Engineers: Reston, VA, USA, 2006; pp. 12-26.

48. Stewart, M.G.; Wang, X.; Nguyen, M.N. Climate change impact and risks of concrete infrastructure deterioration. Eng. Struct. 2011, 33, 1326-1337. [CrossRef]

49. Tang, S.W.; Yao, Y.; Andrade, C.; Li, Z.J. Recent durability studies on concrete structure. Cem. Concr. Res. 2015, 78, 143-154. [CrossRef]

50. Xie, D. Study on the High Performance Concrete Carbonization and Correlative Capability. Ph.D. Thesis, HoHai University, Nanjing, China, 2003.

51. Khaliq, V.; Kodur, V. Properties of Concrete at Elevated Temperatures. ISRN Civ. Eng. 2014. [CrossRef]

52. Saetta, A.V.; Schrefler, B.A.; Vitaliani, R.V. The carbonation of concrete and the mechanism of moisture, heat and carbon dioxide flow through porous materials. Cem. Concr. Compos. 1993, 23, 761-772. [CrossRef]

53. Zhang, H.; LI, G.; Yuan, W. Experimental Study on Carbonization of Concrete; Xi'an Jiaotong University Press: Shaanxi, China, 2006.

54. Xu, H.; Chen, Z.Q.; Li, S.B.; Huang, W.; Ma, D. Carbonation Test Study on Low Calcium Fly Ash Concrete. Appl. Mech. Mater. 2010, 34-35, 327-331. [CrossRef]

55. Atiş, C.D. Accelerated carbonation and testing of concrete made with fly ash. Constr. Build. Mater. 2003, 17, 147-152. [CrossRef]

56. Yoon, I.-S.; Çopuroğlu, O.; Park, K.B. Effect of global climatic change on carbonation progress of concrete. Atmos. Environ. 2007, 41, 7274-7285. [CrossRef]

57. Saha, M.; Eckelman, M. Urban Scale Mapping of Concrete Degradation from Projected Climate Change. Urban Clim. 2014, 9, 101-114. [CrossRef]

58. Meesit, R.; Kaewunruen, S. Vibration characteristics of micro-engineered crumb rubber concrete for railway sleeper applications. J. Adv. Concr. Technol. 2017, 15, 55-66. [CrossRef]

59. Kaewunruen, S.; Meesit, R. Sensitivity of crumb rubber particle sizes on electrical resistance of rubberised concrete. Cogent Eng. 2016, 3, 1126937. [CrossRef]

60. Kaewunruen, S.; Meesit, R.; Mondal, P. Early-age dynamic moduli of crumbed rubber concrete for compliant railway structures. J. Sustain. Cement-Based Mater. 2017, 6, 281-292. [CrossRef]

61. Kaewunruen, S.; Kimani, S.K. Damped frequencies of precast modular steel-concrete composite railway track slabs. Steel Compos. Struct. 2017, 25, 427-442.

62. Bastidas-Arteaga, E.; Stewart, M. Cost-effective design to address climate change impacts. In Eco-Efficient Repair and Rehabilitation of Concrete Infrastructures; Pacheco-Torgal, F., Melchers, R., de Belie, N., Shi, X., Van Tittelboom, K., Perez, A.S., Eds.; Elsevier: New York, NY, USA, 2017.

63. Cai, Y.; Zhao, Y.; Ma, X.; Zhou, K.; Chen, Y. Influence of environmental factors on atmospheric corrosion in dynamic environment. Corros. Sci. 2018, 137, 163-175. [CrossRef]

64. Kaewunruen, S.; Sussman, J.M.; Matsumoto, A. Grand Challenges in Transportation and Transit Systems. Front. Built Environ. 2016, 2, 4. [CrossRef]

(C) 2018 by the authors. Licensee MDPI, Basel, Switzerland. This article is an open access article distributed under the terms and conditions of the Creative Commons Attribution (CC BY) license (http://creativecommons.org/licenses/by/4.0/). 